\title{
PENGGUNAAN MEDIA AUDIOVISUAL UNTUK MENINGKATKAN HASIL BELAJAR KELAS XII IPA 1 SEKOLAH MENENGAH ATAS NEGERI 1 PETANG
}

\author{
Ni Ketut Widani \\ Sekolah Menengah Atas Negeri 1 Petang \\ email : widaniketut@gmail.com
}

\begin{abstract}
ABSTRAK
Penelitian ini dilaksanakan di SMA N 1 Petang pada semester ganjil tahun pelajaran 2013/2014. Penelitian tindakan kelas ini dilaksanakan berawal dari permasalahan yang ditemui peneliti yakni : rendahnya motivasi, dan hasil belajar peserta didik Kelas XII IPA semester 1 pada kompetensi dasar (KD) reaksi redoks tahun-tahun sebelumnya. Sebagai subyek penelitian dipilih Kelas XII IPA 1, dengan obyek penelitian adalah motovasi dan prestasi belajar. Kriteria keberhasilan penelitian: $\bar{X} \geq$ Kriteria Ketuntasan Minimal (KKM), KKM yang ditetapkan adalah 75 , Daya Serap (DS) minimal 75\%, Ketuntasan Klasikal (KK) minimal $80 \%$, Motivasi $\geq 66,17$. Hasil Penelitian menunjukkan penggunaan media audiovisual dapat meningkatkan motivasi dan hasil belajar peserta didik dengan rata-rata motivasi belajar 77,06 dan rata-rata hasil belajar $(\bar{X})=77.03$, Daya Serap $=77,03 \%$, Ketuntasan Klasikal $(\mathrm{KK})=81,15$. Hal ini menunjukan penggunaan media audiovisual dapat meningkatkan motivasi dan hasil belajar peserta didik Kelas XII IPA 1 semester Ganjil Tahun pelajaran 2013-2014 pada Kompetensi Dasar Reaksi Redoks.
\end{abstract}

Kata kunci : PTK, audiovisual, belajar, kimia

\section{ABSTRACT}

This research was conducted in SMA N 1 Petang in odd semester of 2013/2014 School Year. Class Action Research has been carried out from the problem that is: the low motivation and study result of Reaction Redox Basic Competence (KD) in previousyears of first semester of Class XII IPA students. Class XII IPA 1 selected, as research subject with the objects of research are the motivation and learning achievements. With success criteria: $\geq$ Minimum Exhaustiveness Criteria (KKM). The set up KKM is 75; Absorption Power (DS) of at least 75\%; Classic completeness (KK) of at least $80 \%$; Motivation $\geq 66.17$. The results showed that the use of Audiovisual Media can improve the motivation and learning outcomes of students with average learning motivation 77.06 and average learning outcomes $(X)=$ 77.03 Absorption $=77.03 \%$ Classical Exhaustion $(K K)=81,15$. This shows that the use of audiovisual media can improve the motivation and learning outcomes of Class XII IPA 1 Odd semester students of 2013-2014 School Year on Redox Reaction Basic Competence.

Keywords: PTK, audiovisual, learning, chemistry

\section{PENDAHULUAN}

Hasil belajar pada konsep redoks dan elektrokimia yang dicapai peserta didik kelas XII IPA SMA N 1 Petang pada tiap tahunnya sangat rendah yakni dengan ratarata lebih rendah dari KKM yang ditetapkan, dengan ketuntasan kurang dari $50 \%$. 
Hasil yang rendah ini diduga berkaitan erat dengan suasana kelas yang pasif saat proses pembelajaran. Siswa lebih banyak diam, sehingga tidak terjadi komunikasi timbal balik. Pertanyaan yang diberikan guru sering kali akhirnya dijawab dan dibahas oleh guru sendiri karena tidak mendapat respon dari peserta didik..

Materi pelajaran kimia banyak yang bersifat abstrak, rendahnya daya imajinasi peserta didik untuk memahami sesuatu yang bersifat abstrak, serta kurangnya contoh reaksi redoks dalam kehidupan sehari-hari yang dapat membantu siswa memahami proses mikro yang terjadi pada sel elektrokimia, merupakan faktor yang mengakibatkan rendahnya ketuntasan dan hasil belajar peserta didik. Terlebih lagi materi pembelajaran konsep redoks di kelas XII banyak melibatkan persoalan yang berdasarkan proses mikro baik pada sel Volta maupun sel Elektrolisa sehingga sulit dipahami peserta didik.

Berdasarkan permasalahan tersebut, untuk meningkatkan hasil belajar perlu adanya peningkatan kualitas pembelajaran dengan dukungan media pembelajaran yang memadai. Menurut Djamarah dkk. (2010) dalam kegiatan pembelajaran ketidakjelasan materi yang disampaikan dapat dibantu dengan menghadirkan media sebagai perantara.

Materi pembelajaran yang bersifat abstrak akan lebih nyata dengan bantuan media. Media dapat mewakili apa yang kurang mampu guru jelaskan dengan katakata atau

Untuk mewujudkan hal tersebut, pemberian tindakan berupa penggunaan Teknologi Informasi dan Komunikasi (TIK) dalam bentuk tayangan audiovisual sebagai media pembelajaran diharapkan dapat menyederhanakan atau menjelaskan materi pembelajaran yang bersifat abstrak menjadi lebih nyata sehingga lebih mudah dipahami. Media pembelajaran yang baik akan menarik perhatian siswa dan membuat mereka lebih bersemangat untuk belajar.

Setiap metode pembelajaran tentunya harus diuji untuk megetahui keefektifannya. Metode penelitian tindakan kelas merupakan metode penelitian yang paling sesuai untuk mengetahui keberhasilan suatu media pembelajaran dalam membantu proses belajar mengajar. Bertitik tolak dari latar belakang tersebut masalah yang dapat dirumuskan adalah sebagai berikut:

1. Apakah penggunaan media pembelajaran audiovisual dapat meningkatkan aktivitas belajar siswa pada pokok bahasan konsep Redoks ?

2. Apakah penggunaan media pembelajaran audiovisual dapat meningkatakan hasil belajar pada pokok bahasan konsep Redoks ?

\section{MEDIA PEMBELAJARAN}

Kata media berasal dari bahasa latin dan merupakan bentuk jamak dari medium. Secara harfiah berarti perantara atau pengantar. Dengan demikian media adalah bentuk-bentuk komunikasi baik tercetak maupun audiovisual serta peralatannya. Pembelajaran adalah usaha-usaha belajar agar terjadi proses pembelajaran dari peserta didik (Sadiman dkk. 2011) Jadi Media pembelajaran adalah Segala sesuatu yang dapat menunjang pikiran,perasaan dan minat peserta didik sehingga proses pembelajaran terjadi.

Pembagian Media menurut jenisnya:

1. Media Auditif, adalah media yang mengandalkan suara saja seperti radio. 
2. Media Visual, adalah media yang mengandalkan indra penglihatan,seperti gambar dan foto.

3. Media Audiovisual Diam, yaitu media yang menampilkan suara dan gambar diam

4. Media Audiovisual Gerak,yaitu media yang menampilkan unsur suara dan gambar yang bergerak sepeti Video Casstte dan film

Audiovisual berasal dari dua kata yaitu audio dan visual. Audio ; bunyi/suara. Visual ; penglihatan. Jadi media Audiovisual yang dimaksudkan adalah : Alat bantu penyampaian informasi yang menampilkan suara dan gambar bergerak maupun diam.

Levie dan Leinz mengemukakan empat fungsi media khususnya media visual yaitu : (a) fungsi atensi ,yakni menarik dan mengarahkan perhatian siswa untuk berkonsentrasi pada materi pelajaran yangdi tampilkan atau menyertai teks materi pelajaran ; (b) fungsi afektif yaitu menggugah emosi dan sikap siswa ; (c) fungsi kognitif yaitu memperlancar pencapaian tujuan untuk mengingat,memahami informasi yang terkandung; dan (d) fungsi kompensatoris yaitu memberikan konteks untuk mengakomodasikan siswa yang lemah dan lambat menerima dan memahamimateri pelajaran yang disajikan dengan teks atau disajikan secara verbal (dalam Arsyad 2009).

\section{MOTIVASI BELAJAR}

Menurut Winkel (1989) motivasi adalah motif yang sudah menjadi aktif pada saat-saat melakukan percobaan, sedangkan motif sudah ada dalam diri seseorang jauh sebelum orang itu melakukan suatu perbuatan. Dalam Sardiman (1986) disebutkan motivasi adalah perubahan energi dalam diri seseorang yang ditandai dengan munculnya feeling dan didahului dengan tanggapan terhadap adanya tujuan. Faktor-faktor yang mempengaruhi motivasi belajar adalah:

Kematangan. Dalam pemberian motivasi, faktor kematangan fisik, sosial dan psikis haruslah diperhatikan, karena hal itu dapat mempengaruhi motivasi. Jika tidak memperhatikan kematangan, maka akan mengakibatkan frustasi dan hasil belajar tidak optimal.

1. Usaha yang bertujuan. Setiap usaha yang dilakukan mempunyai tujuan yang ingin dicapai. Semakin jelas tujuan yang ingin dicapai, akan semakin kuat dorongan untuk belajar.

2. Pengetahuan mengenai hasil dalam motivasi. Dengan mengetahui hasil belajar, peserta didik terdorong untuk lebih giat belajar. Apabila hasil belajar mengalami kemajuan, peserta didik akan berusaha untuk mempertahankan dan meningkatkan belajarnya untuk tetap berprestasi. Prestasi rendah menjadikan peserta didik giat belajar guna memperbaikinya.

3. Partisipasi. Dalam kegiatan pembelajaran perlu diberikan kesempatan pada peserta didik untuk berpartisipasi dalam seluruh kegiatan belajar. Dengan demikian kebutuhan peserta didik akan kasih sayang dan kebersamaan dapat diketahui.

4. Penghargaan dan hukuman. Pemberian penghargaan membangkitkan rasa percaya diri sehingga peserta didik lebih bersemangat untuk melanjutkan, 
mempelajari atau mengerjakan sesuatu. Tujuan pemberian penghargaan adalah karena telah melakukan kegiatan belajar yang baik, ia akan melanjutkan kegiatan belajarnya sendiri di luar kelas. Sedangkan hukuman sebagai imbalan yang negatif tetapi kalau diberikan secara tepat dan bijak bisa menjadi alat motivasi.

\section{Prestasi Belajar}

Prestasi belajar adalah hasil
interaksi berbagai faktor mempengaruhi baik dari dalam diri (faktor internal) maupun dari luar (faktor eksternal) individu (Ahmadi, 1991). Prestasi belajar adalah hasil yang dicapai sebaik-baiknya menurut kemampuan anak pada waktu tertentu terhadap hal-hal yang dikerjakan atau dilakukan.

Prestasi belajar merupakan bukti keberhasilan yang telah dicapai olehseseorang. Jadi dapat disimpulkan bahwa prestasi belajar adalah hasil maksimum yang dicapai peserta didik setelah melakukan usaha belajar dengan dipengaruhi interaksi dari berbagai faktor, baik yang berasal dari dalam diri (faktor internal) ataupun dari luar diri (faktor eksternal) peserta didik

\section{Hipotesis Tindakan}

Hipotesis tindakan yang dapat diajukan adalah:

1. Penggunaan media pembelajaran Audiovisual dapat meningkatkan motivasi belajar reaksi Redoks kelas XII IPA 1 tahun Pelajaran 2013/2014.

2. Penggunaan media pembelajaran audiovisual dapat meningkatkan prestasi belajar reaksi redoks kelas
XII IPA 1 semester 1 tahun pelajaran 2013/2014

\section{METODOLOGI}

Jenis Penelitian.

Penelitian ini merupakan Penelitian Tindakan Kelas (PTK) yang dilakukan secara mandiri, dengan upaya peningkatan prestasi belajar kimia menggunakan media audiovisual yang melibatkan peserta didik dalam proses pembelajaran.

\section{Tempat, Subjek dan Objek Penelitian.}

Tempat yang dipilih peneliti untuk melakukan penelitian adalah SMA Negeri 1 Petang yang merupakan tempat tugas peneliti. Subjek penelitian adalah peserta didik kelas XII IPA semester satu tahun pelajaran 2013/2014. Subjek penelitian dipilih berdasarkan hasil penilaian motivasi dan prestasi belajar yang rendah pada tahun - tahun sebelumnya (lebih rendah dari KKM yang ditetapkan). Objek penelitian dari PTK ini adalah motivasi dan prestasi belajar Reaksi Redoks peserta didik kelas XII IPA1 semester satu SMAN 1 Petang tahun pelajaran 2013/2014.

Prosedur Penelitian

Pelaksanaan Penelitian Tindakan Kelas ini melalui beberapa siklus, siklus tersebut terdiri dari refleksi awal, perencanaan, pelaksanaan, pengamatan dan

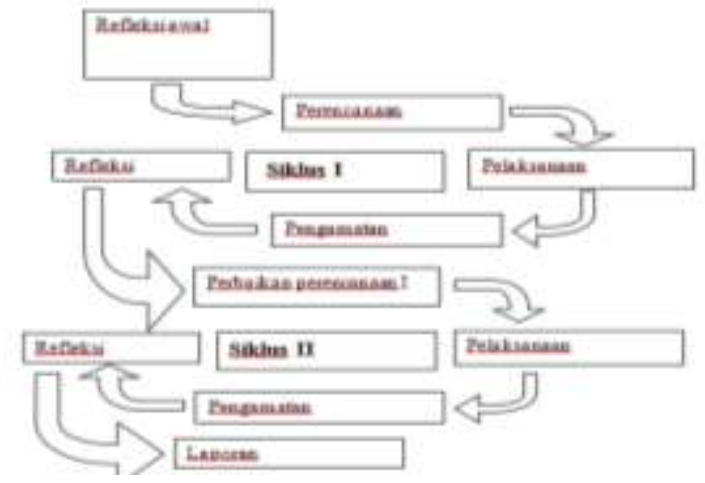

refleksi. Prosedur penelitian disajikan secara lengkap pada gambar 1 . 
Gambar 1.Model Siklus PTK

(Sumber : Iskandar, 2009)

\section{Tekhnik Pengumpulan Data}

1. Data motivasi belajar peserta didik dalam proses pembelajaran dikumpulkan menggunakan angket motivasi belajar

2. Data prestasi belajar peserta didik dalam proses pembelajaran dikumpulkan dengan tes prestasi belajar

\section{Teknik Analisis Data}

Metode yang dipergunakan dalam pengolahan data adalah metode analisis deskriptif yaitu cara pengolahan data dengan menggunakan rumus-rumus matematika yang sederhana guna memperoleh kesimpulan umum. Pada PTK ini, data dianalisis sejak tindakan pembelajaran dilaksanakan, dikembangkan selama proses refleksi sampai proses penyusunan laporan. Analisis data kuantitatif dilakukan dengan mencari hasil belajar peserta didik pada pelaksanaan tes tentang Konsep Reaksi Reaksi Redoks, yaitu dari siklus awal sampai siklus berikutnya. Penarikan kesimpulan dilakukan dengan membandingkan antara hasil belajar pada refleksi awal dan pengamatan pada akhir siklus. Tekhnik anlisis data dalam penelitian ini dibagi menjadi dua yaitu tekhnik analisis data motivasi belajar dan tekhnik analisis data prestasi belajar.

1. Teknik analisis data motivasi belajar

Kriteria penggolongan tingkat motivasi belajar peserta didik disusun berdasarkan nilai rata-rata motivasi belajar peserta $\operatorname{didik}(\bar{X})$. Skor rata-rata motivasi peserta didik yang diperoleh dari perhitungan dibandingkan dengan kriteria penggolongan yang ditetapkan (tabel 1).
Dengan demikian akan dapat ditentukan motivasi belajar peserta didik selama proses pembelajaran.

Tabel 1Penggolongan Motivasi Belajar Peserta Didik

\begin{tabular}{ll}
\hline Kriteria & Kategori \\
\hline $80 \leq \bar{X}$ & Sangat tinggi \\
$66,67 \leq \bar{X}<80$ & Tinggi \\
$66,17 \leq \bar{X}<66,67$ & Cukup \\
$40 \leq \bar{X}<66,17$ & Rendah \\
$\bar{X}<40$ & Sangat rendah \\
\hline \multicolumn{2}{r}{ (dimodifikasi dari Nurkancana dan } \\
\multicolumn{2}{r}{ Sunartana, 1992) }
\end{tabular}

2. Tekhnik analisis data prestasi belajar

Data prestasi belajar dianalisis dengan menentukan rata-rata hasil tes ( $\bar{X}$ ), daya serap (DS) dan ketuntasan klasikal (KK).Nilai rata-rata kelas digolongkan menurut tabel 2.

Tabel 2Penggolongan Prestasi Belajar Peserta Didik

\begin{tabular}{ll}
\hline Kriteria & Kategori \\
\hline $86 \leq \bar{X}$ & Sangat tinggi \\
$71 \leq \bar{X}<85$ & Tinggi \\
$55 \leq \bar{X}<70$ & Cukup \\
$41 \leq \bar{X}<55$ & Rendah \\
$\bar{X}<40$ & Sangat rendah \\
\hline \multicolumn{2}{r}{ (dimodifikasi dari Nurkancana dan } \\
\end{tabular}

Menentukan daya serap

$$
\begin{aligned}
& \text { DS }=\frac{\overline{\boldsymbol{X}}}{\text { Nilai maks }} \times 100 \% \\
& \text { Keterangan : } \\
& \begin{aligned}
\mathrm{DS} & =\text { Daya serap } \\
& =\text { Nilai rata-rata kelas }
\end{aligned}
\end{aligned}
$$

Menentukan ketuntasan klasikal 


$$
\mathrm{KK}=\frac{N i}{N} \times 100 \%
$$

Keterangan :

KK $=$ Ketuntasan klasikal

$\mathrm{Ni}=$ Banyaknya peserta didik yang memperoleh nilai $\geq$ KKM $(\geq 75$ )

$\mathrm{N}=$ Banyaknya peserta didik yang ikut tes

\section{Kriteria Keberhasilan}

Penelitian ini dikatakan telah berhasil jika kriteria yang ditetapkan telah terpenuhi. Adapun kriteria tersebut adalah :

a. $\bar{X} \geq$ Kriteria Ketuntasan Minimal (KKM). KKM yang ditetapkan adalah 75

b. Daya Serap (DS) minimal $75 \%$

c. Ketuntasan Klasikal (KK) minimal $80 \%$

d. Motivasi $\geq 66,17$

\section{HASIL PENELITIAN DAN PEMBAHASAN}

Penelitian ini dilaksanakan dalam dua siklus karena pada siklus II sudah mencapai kriteria keberhasilan dengan nilai rata-rata motivasi belajar 77,06 (diatas cukup) bahkan tergolong tinggi. Nilai ratarata prestasi belajar pada akhir siklus II sebesar 77,03, daya serap $77,03 \%$ dan ketuntasan klasikal diatas $81.25 \%$. Secara umum motivasi dan prestasi belajar peserta didik dapat digambarkan dalam tabel 3.

Secara teori, media pembelajaran audiovisual mempengaruhi prestasi belajar. Hal tersebut dapat dijelaskan sebagai berikut.Menurut Bruner (1960) dalam Sagala (2010) proses pembelajaran dapat dibedakan menjadi tiga fase. Ketiga fase tersebut dikenal dengan teori belajar Bruner, dapat diuraikan sebagai berikut :

1. Tahap Enaktif
Pada tahap ini anak secara langsung terlibat dalam memanipulasi (mengotakatik) objek. Maksudnya pada tahap ini anak belajar sesuatu pengetahuan di mana pengetahuan itu dipelajari secara aktif dengan menggunakan benda-benda kongkret atau menggunakan situasi yang nyata.

2. Tahap Ikonik

Dalam tahap pembelajaran ikonik ini menjelaskan pengetahuan di mana pengetahuan itu dipresentasikan (diwujudkan) dalam bentuk bayangan visual (visual imaginery), gambar, atau diagram, yang menggambarkan kegiatan konkret yang terdapat pada tahap sebelumnya.

3. Tahap simbolis.

Dalam tahap ini bahasa adalah pola dasar simbolik , anak memanipulasi simbolsimbol atau lambang-lambang objek tertentu. Pada tahap simbolik ini, pembelajarandipresentasikan dalam bentuk simbol-simbol abstrak, yaitu simbol-simbol yang dipakai berdasarkan kesepakatan orang-orang dalam bidang yang bersangkutan, baik simbol verba, lambang matematika, maupun lambang-lambang abstrak yang lain.

Media audiovisual akan membantu proses belajar pada tahap enaktif dan ikonik dalam teori Bruner, sehingga siswa akan lebih tertarik untuk belajar dan prestasi belajarnya dapat lebih ditingkatkan. Teori tersebut sesuai dengan pendapat Suprijanto (2007) ada beberapa manfaat alat bantu audiovisual dalam pengajaran, antara lain :

1. Membantu memberikan konsep pertama atau kesan yang benar

2. Mendorong minat

3. Meningkatkan pengertian yang lebih baik

4. Melengkapi sumber belajar yang lain 
5. Menambah variasi metode mengajar

6. Meningkatkan keingintahuan intelektual

7. Cenderung mengurangi ucapan dan penglangan kata yang tidak perlu

8. Membuat ingatan terhadap pelajaran lebih lama

9. Dapat memberikan konsep baru dari sesuatu di luar pengalaman biasa

Penyebaran angket motivasi belajar dilakukan pada pertemuan terakhir dari masing-masing siklus. Berdasarkan hasil penelitian, diperoleh skor rata-rata motivasi belajar peserta didik pada siklus I adalah 65,63. Menurut kriteria penggolongan motivasi belajar peserta didik, maka tingkat motivasi belajar peserta didik pada siklus I masih rendah, sehingga penelitian perlu dilanjutkan ke siklus II. Pada pertemuan terakhir dari siklus II dilakukan lagi penyebaran angket motivasi belajar. Hasil observasi tentang motivasi belajar peserta didik pada siklus II diperoleh skor rata-rata motivasi belajar peserta didik 77,06. Menurut kriteria penggolongan motivasi belajar, maka tingkat motivasi belajar peserta didik pada akhir siklus II adalah tinggi.

Berdasarkan pengamatan prestasi belajar peserta didik setelah tindakan siklus I (ditunjukkan pada tabel 3.) diperoleh skor rata-rata prestasi belajar peserta didik adalah 70,00. Data tersebut dikumpulkan melalui tes prestasi belajar. Menurut kriteria penggolongan prestasi belajar, maka prestasi belajar peserta didik pada siklus I adalah cukup. Data daya serap yang diperoleh adalah 70

Data prestasi belajar peserta didik setelah tindakan siklus II ditunjukkan pada tabel

Tabel 3. Data motivasi dan prestasi siswa setelah penelitian

\begin{tabular}{ccccc}
\hline No & Variabel yang diamati & Siklus & Nilai rata-rata & Keterangan \\
\hline 1 & Motivasi belajar & I & 65,63 & Rendah \\
2 & & II & 77,06 & Tinggi \\
3 & Prestasi belajar & I & 70,00 & Cukup \\
4 & & II & 77,03 & Tinggi \\
\hline
\end{tabular}


Dari tabel tersebut diperoleh skor rata-rata prestasi belajar peserta didik yang dikumpulkan melalui tes prestasi belajar adalah 77,03 Menurut kriteria penggolongan prestasi belajar, maka prestasi belajar peserta didik pada siklus II adalah tinggi dengan daya serap 77,03 \%,dan ketuntasan klasikal 81,25\%.

Menurut data yang disajikan pada tabel 3 dapat dilihat bahwa adanya peningkatan yang cukup signifikan dari segi motivasi dan prestasi belajar peserta didik dari siklus I ke siklus II. Hal ini menunjukkan penggunaan media pembelajaran Audiovisual (misalnya : video) dapat meningkatkan motivasi dan prestasi belajar pada Konsep Reaksi redoks peserta didik kelas XII IPA1 SMA Negeri 1 Petang tahun pelajaran 2013/2014. Oleh karena itu, penelitian ini dianggap berhasil dilaksanakan sampai siklus II karena telah memenuhi kriteria keberhasilan dengan nilai rata-rata motivasi belajar minimal cukup, nilai rata-rata prestasi belajar minimal 75 , daya serap minimal $75 \%$ dan ketuntasan klasikal minimal $80 \%$.

\section{PENUTUP}

Berdasarkan hasil analisa data dan pembahasan maka dapat disimpulkan hal-hal sebagai berikut :

1. Penggunaan media Audiovisual (video) dapat dapat meningkatkan motivasi belajar pada konsep Reaksi Redoks peserta didik kelas XII IPA 1 SMA N 1 Petang tahun 2013/2014. Skor rata-rata motivasi belajar 65,63 pada siklus I dan 77,06 pada akhir siklus II
2. Penggunaan Media Audiovisual dapat meningkatkan prestasi belajar Konsep Reaksi Redokspeserta didik kelas XII IPA 1 SMA N 1 Petang tahun 2013/2014, dengan skor rata-rata 70,00 pada siklus I dan pada siklus II meningkat menjadi 77.03

\section{DAFTAR PUSTAKA}

Ahmadi, A. dan Widodo S. (1991), Psikologi Belajar, Jakarta: Rineka Cipta.

Djamarah, Syaiful B. dan Anwar Z. (2010), Strategi Belajar Mengajar, Jakarta: Rineka Cipta.

Nurkancana, Wayan dan Sunartana, (1990), Evaluasi Hasil Belajar, Surabaya: Usaha Nasional.

Sadiman, A. S., R Rahardjo, Anung H. dan Rahardjito, (2011) Media Pendidikan: Pengertian, Pengembangan dan Pemanfaatannya, Jakarta: Rajawali Pers.

Sagala, S. (2007). Konsep dan Makna Pembelajaran. Bandung: Alfabeta

Sardiman, A.M, (1986), Interaksi dan Motivasi Belajar Mengajar. Jakarta: Rajawali Pers.

Suprijanto, (2007), Pendidikan Orang Dewasa, Jakarta: Bumi Aksara.

Winkel, W.S., (1989), Psikologi Pengajaran, Jakarta: Gramedia 